\title{
O PLC 180/2008: UM PROJETO DE LEI QUE NÃO OLHA PARA OS PROBLEMAS DA EDUCAÇÃO E INCLUI PROPOSTAS EXCÊNTRICAS PARA A SELEÇÃO NO ENSINO SUPERIOR
}

Aprovado recentemente no Senado, o PLC 180/2008 dispõe sobre o ingresso nas Universidades Federais e nas Instituições Federais de Ensino Técnico de nível médio e dá outras providências. Este PL contempla dois aspectos de natureza distinta que podem ser analisados separadamente: a reserva de vagas e o mecanismo de seleção. O objetivo deste texto é mostrar que este projeto de lei, além de não atingir o cerne dos problemas que causam as imensas diferenças de oportunidades entre os jovens brasileiros, induz práticas que podem piorar ainda mais o ensino médio no Brasil.

O texto do PL decreta que no mínimo $50 \%$ das vagas das "instituições federais de educação superior vinculadas ao Ministério de Educação" serão reservadas "para estudantes que tenham cursado integralmente o ensino médio em escolas públicas". Estas vagas reservadas "serão preenchidas, por curso e turno, por autodeclarados pardos, pretos e indígenas" em proporções que refletem as percentagens de "pardos, pretos e indígenas" na população dos Estados. O Supremo Tribunal Federal já se manifestou sobre a constitucionalidade do assunto entendendo que a reserva de cotas não fere a autonomia das universidades que, aparentemente, teria sido consagrada no Art. 207 da Constituição de 1988. Quiçá a partir desta decisão do STF a ação do congresso estende o conceito da constitucionalidade das cotas e impõe uma reserva de vagas que se aplica a todas as Universidades Federais.

Isto posto é apropriado analisar, ainda que sumária e preliminarmente, a relação entre educação e renda no Brasil. Apesar da economia brasileira ocupar o $7^{\circ}$ lugar quando se comparam os PNB's do mundo, a distribuição de renda é tão iníqua quanto o nível educacional. Ocupamos a lamentável $16^{a}$ posição $(0,512)$ quando se ordenam 136 países usando o índice Gini desde a pior distribuição de renda (Namíbia $=0,707)$ até a melhor (Suécia $=0,23)$. A distribuição de renda, a tardia liberação dos escravos, o preconceito e a discriminação são elementos que se somam aos indicadores que mostram a enorme distância que separa os brasileiros em grupos e castas.

Os estudantes brasileiros ocupam os últimos lugares quando se medem conhecimentos em leitura, matemática ou ciências no ensino fundamental (PISA).

A percentagem da população economicamente ativa (PEA) sem instrução ou com menos de 1 ano de estudo $(4,8 \%, 2009)$, de 1 a 3 $(5,48 \%, 2009)$ e a de 4 a 7 anos de estudo (14,36\%, 2009) vem caindo na última década enquanto a de 8-10 anos de estudo se mantém estável $(10,72 \%, 2009)$. A \% da PEA com 11 a 14 anos de estudo aumentou moderadamente $(20,5 \%, 2009)$.

A iniquidade é ainda mais dramática quando se consideram os dados sobre a distribuição educacional na faixa de 17-25 anos, intervalo aceito internacionalmente como o período ideal para completar o ensino superior. Em 2009, $21 \%$ dos brasileiros desse grupo não tinham completado o ensino fundamental, $27 \%$ tinham completado o ensino fundamental, $33 \%$ o ensino médio e somente $19 \%$ tiveram acesso ao ensino superior. Os resultados do ENEM mostram que não mais da metade dos concluintes do ensino médio estão qualificados para ingresso no ensino superior. Existem diferenças significativas entre brancos e não brancos em todas essas condições. Dentre os que não concluíram o ensino fundamental em 2009, os brancos são a metade dos não brancos. A relação brancos/não brancos que tiveram acesso ao ensino superior foi 2,5 em 2009. Estas cifras mostram que as diferenças de oportunidades entre brancos e não brancos, quando se comparam categorias comparáveis, são da ordem de 2 . Esta diferença aumenta quando se considera renda. No ensino superior os estudantes brancos mais ricos têm 12,7 vezes mais probabilidade de acesso quando comparados com os mais pobres, enquanto para os não brancos a relação rico/pobre sobe para 24,7. "Estes indicadores, portanto, nos levam a concluir que as diferenças existentes entre os mais ricos e os mais pobres são bem mais acentuadas que aquelas observadas entre brancos e não brancos". ${ }^{1}$

Se a diminuição da iniquidade depende de nível educacional, qual o papel do PL 180/2008 em tudo isto? À luz dos dados acima: nenhum. Investimento na qualidade do ensino fundamental, na qualidade, extensão e universalização do ensino médio nada a ver tem com um sistema de cotas único, imposto por força da lei a todo o país, a cada uma das universidades federais em qualquer lugar de um país continental.

A mudança nos critérios de seleção dos alunos nas universidades "tendo como base o Coeficiente de Rendimento (CR), obtido por meio de média aritmética das notas ou menções obtidas no período, considerando-se o currículo comum a ser estabelecido pelo Ministério da Educação" é um dos elementos mais perturbadores do PL. Ainda que a ética imperasse em todo o sistema de ensino, a inexistência de um mecanismo de avaliação comum para todas as escolas de ensino médio faz com que médias aritméticas, obtidas em escolas diferentes num país continental, sejam inúteis como mecanismo seletivo. Não existe possibilidade concreta de avaliar se as notas obtidas por um aluno na escola $x$ representam, ou não, a mesma capacidade de atingir domínio de conteúdos na escola $y$.

Se o primeiro artigo do PL não contribui para compreender o problema da iniquidade, o segundo cria um novo elemento de cerceamento das iniciativas e promoção das diferenças. Cerceamento a iniciativas, pois diversas universidades públicas implantaram mecanismos que estimulam a inclusão. Ao invés de estarem sustentados por argumentos arbitrários, os mecanismos de inclusão já implantados são baseados em evidências e levam em conta realidades locais. Assim, melhoram o ensino secundário com parâmetros que se adaptam a realidades concretas e distintas em cada região do país. Uma seleção por média, num sistema heterogêneo de escolas de ensino médio só pode conduzir a uma competição onde o prêmio não se relaciona com a qualidade de ensino, mas com a capacidade de cada escola de aumentar as médias a qualquer custo. O PL cria, portanto, incentivos para estabelecer mecanismos de burla que no ensino médio visem aumento das médias ao invés de cobrança de conteúdos.

Assim, a imposição de cotas mandatórias e as mudanças propostas para o ingresso não são respostas às necessidades reais que exigem do Brasil ações para diminuir o fosso que separa os que têm educação (ricos) dos que não foram educados (pobres).

Hernán Chaimovich IQ/USP

\section{NOTA DOS EDITORES}

O editorial foi recebido antes da definição da promulgação da Lei $n^{\circ} 12.711$, de 29 de agosto de 2012 onde se vetou o Artigo $2^{\circ}$ que tratava dos critérios de ingresso.

\section{REFERÊNCIA}

1. de Andrade, C. Y.; Ensino Superior UNICAMP, 31/07/2012. 